\title{
Alžbeta Dufferová
}

\author{
University of Religion in Győr, Department of Philosophy, Department \\ of Theology
}

\section{A Philosophical view of Internet Communication}

\section{Filozoficzne spojrzenie na komunikację za pośrednictwem Internetu}

\begin{abstract}
SUMMARY:
The Internet, with its brilliant capacity to accumulate, classify, and distribute a vast amount of data, has exploded into an incredible colossus. Our world is hard to imagine without it. The paper "A Philosophical view of Internet Communication" examines the question of whether and to what extent the Internet corresponds to the actual needs of man and society. This presentation captures the Internet's overwhelming impact, but it does not even address some of its serious shortcomings. The Internet has served and enriched the generation that built it, but the coming generation has no concept of a world without the Internet.

What does this mean? It is true that the young "internet" generation teaches the older "noninternet" generation easily and with certitude but can no longer make sense of its own unique life with similar ease. It is not the most important thing in life to be proficient in computer matters.

What is of greater concern is that these skills in the younger generation are receding into the background vis-à-vis the fact that young people understand neither themselves nor others? Does the "computer culture" produce some sort of vacuum in the mind of man? How is it possible that a seven-year-old child can write comprehensible texts on a computer, but cannot go to school because it can't go to the toilet by itself? What happened to the "rose" cultivated by Little Prince of Saint-Exupery?
\end{abstract}

KEYWORDS: Internet, Aim, Communication, Meaning, Quality, Life

\section{STRESZCZENIE:}

Internet jako miejsce służące do zbierania, klasyfikowania i rozpowszechniania ogromnej ilości danych rozwinął się w ostatnich czasach do niewyobrażalnych rozmiarów. Trudno sobie wyobrazić funkcjonowanie współczesnego świata bez jego obecności. Artykuł „Filozoficzne spojrzenie na komunikację za pośrednictwem Internetu" poszukuje odpowiedzi na pytanie: czy i w jakim stopniu Internet odpowiada na rzeczywiste potrzeby człowieka i społeczeństwa. Niniejsza publikacja przedstawia ogromny wpływ Internetu, ale nie rozwiązuje dylematów powstałych z niektórych jego poważnych niedociągnięć. Internet służył i ubogacał pokolenie, które je stworzyło, ale kolejne pokolenie nie ma pojęcia o świecie bez Internetu. Co to znaczy? Prawdą jest, że młode „internetowe” pokolenie z łatwością i pewnością uczy starszą "nie-internetową" generację, jednak poczucia wyjątkowości swojego własnego życia nie potrafi już odnaleźć z podobną łatwością. Tymczasem, najważniejszą rzeczą w życiu nie jest bycie biegłym w sprawach komputerowych. Co gorsza, wydaje się, że umiejętność ta doprowadza do problemów ze zrozumieniem siebie i innych. Czy „kultura komputerowa" tworzy jakąś próżnię w umyśle człowieka? Jak to możliwe, że siedmioletnie dziecko, które potrafi pisać zrozumiałe teksty na komputerze, nie może chodzić do szkoły, ponieważ nie jest $\mathrm{w}$ stanie samodzielnie korzystać z toalety? Co się stało z "różąa, tak starannie pielęgnowaną przez Małego Księcia Saint-Exuperego?

\section{SŁOWA KLUCZOWE:}

Internet, cel, komunikacja, znaczenie, jakość, życie 


\section{INTRODUCTION}

Man has always been enchanted by his own inventions, sometimes so much that he ceases to be pretentious and unworthy of evil that can destroy him. It happens whenever he stops, just for a moment, to be aware that he is a fake creature. Well, the "devil is in the details ... [and] the answer ... will always be 'it depends" ${ }^{\prime \prime}$. The billions of messages that people exchange on the Internet during a 24-hour period have become the reality we live in all the time. But it should be noted that the initial enthusiasm regarding these incredible possibilities for communication has cooled down. Perhaps because mankind is becoming more and more aware of its responsibility?! Of course, each person with their own pace and the way they can perceive their own worlds and the world surrounding them.

\section{It is not the most important thing in life to be proficient in computer matters.}

Since "the mid-1990s scholars ... have explored the digital in many ways, as a sit for exchange and sharing of resources, a tool for new methods of analysis, and an object of critical inquiry. ... [T] he rapidly expanding scope and changing nature of 'the digital' and the newly emerging methods ... called for a more robust and sustained engagement with it"2. Recently, I learned the results of a student's research project ${ }^{3}$ that explored positive and negative elements in social network-

${ }^{1} \mathrm{~J}$. Baer, The Devil Is in the Details: Why the Answer to Most Questions About Creativity Will Always Be „It Depends“, p. 297.

${ }^{2}$ M. Yoshihara, Editor's Note, "American Quarterly. Special Issue. Toward a Critically Engaged Digital Practice: American Studies and the Digital Humanities" 2018/70, no. 3, p. vii.

${ }^{3}$ There are many articles, studies on the prevention of the negative impact of cybernetics on the youngest generation. Let me give one example which comes from a student research project: "In the years 2010-2011, in the Czech Republic, research was carried out with 1003 teachers and 3166 students of primary school to find about aggressive behaviour patterns among pupils (Csémy, L. et al., 2013). It has been found and that up to $94.3 \%$ of primary school teachers consider cyber bullying to be a potentially threatening subject for primary school pupils, and the primary school pupils were found to have detected someone by mobile and subsequently publishing the picture, $37.7 \%$ of pupils being aggrieved in this form of aggression. Republic at primary and secondary schools research on cyber bullying of teachers (Kopecky, 
ing communication: About $80 \%$ were negative or indifferent and only $20 \%$ were positive or encouraging. No elaboration is necessary. It is enough to read some comments on events, whether in the public or private sector. One cannot have any good feelings about them because of the vulgarity and cruelty, gossip or accusations contained in them. Looking at this in general, not only in terms of ethics and moral philosophy, one must ask why there is so much rage, bitterness and verbal violence, instead of satisfaction from new and fast communication possibilities. It is clear that the problem requires a detailed analysis at multiple levels.

Another worrisome idea that could come to mind is whether and to what extent the Internet is enabling the expression of the deeper emotional turbulence that engulfs man and society.

As objective information continues to expand exponentially, there is a need to choose and to choose only one piece of the vast amount available in every sector of human endeavour. The art of choosing correctly, especially when searching for the three great philosophical goals (the true, the good, and the beautiful) comes at a great price. Too often, one tends to choose what is easier, more accessible, and cheaper; one settles for a compromise that ultimately leads to bitter disappointment, and perhaps, guilt feelings. But the greatest of them most often dwells in him. One of the most serious shortcomings is this one: Not everybody knows in time that not everything that can be seen and known is useful to them. To get the right resolution, to choose one of the most important and needed, requires maturity.

\section{The art of choosing correctly, especially when searching for the three great philosophical goals (the true, the good, and the beautiful)} comes at a great price.

Szotkowski, 2016b). According to research, the victim of some of the signs of cyber bullying has become $21.73 \%$ of teachers (1118 of 5136)." I. Emmerová, Učitel' ako obet' kybernetických útokov žiakov. Výskum a prevencia, "Manažment školy v praxi. Odborný mesačník pre školy a školské zariadenia. Odborný mesačník pre školy a školské zariadenia” 2018, no. 10, p. 18. 
Can then an individual, a young person, even a child mature when they spend hours on the Internet instead of interacting with other people or in real situations? The answer is no. For every man and woman, every day has 24 hours. The question is how this limited time is used and for what purpose. The answer is to hand and within everyone's power. While a child is small, the parents take responsibility; gradually the school and society do their part; but as the child grows, its responsibility grows or should grow accordingly.

Another important question in this context is how to make the best use of our limited time. A French proverb remarks "Tout avec mesure" [Everything according to measure]. But, how does one measure out the appropriate amount of time? How can we divide our time between the Internet and everything else? If we ourselves have problem with time - how can we teach our young children and adolescents? This depends on many factors and principles. The principle that nobody gives what they do not have is valid also here and it is another reason why we must strive to recognize values that cannot be bought for money or found on Google or the Internet.

This presentation is divided into four parts - The Current "Internet" Generation and the Worries Caused by it; the (real or) actual needs of man and society; the Internet and Society: Who Controls Whom; the "rose" grown by Little Prince. Of these parts, some objectives of the study are also presented: To consider what the actual and superfluous needs of a person are and to seek a way to correctly distinguish between them; to examine the advantage of controlling the Internet versus lack of such control in the lives of young people; to try to sketch out some likely errors in the reductionist scientific thinking of the past two centuries; to reflect on the relationship between the reductionist mentality (philosophy) and the technocratic tendency, the return to growing one's own "rose", which is the most exuberant part of our being - psyche.

\section{THE CURRENT “INTERNET” GENERATION AND THE WORRIES CAUSED BY IT}

Modern technologies penetrate many areas of our lives and bring, of course, a lot of positives. The current generation of elementary and secondary school pupils perceives the Internet and information technologies as a normal part of life. They are part of Generation Z (born after 2000) or Alpha Generations (after 2010) and have not experienced a world without modern technology, without computers 
and the Internet. We know and experience that they often control advanced technology as adults. Children often know more about electronics than their parents and teachers. Of course, this is also associated with risk. Ingrid Emmer of Catholic University in Slovakia examines the risks of cyber-attacks that consist of the speed of content distribution and the constant accessibility of disparaging, aggressive and untrue information to many people. It lists several typical forms of cyber-attacks. Let me name at least a few examples: cyber baiting (provoking a teacher and filming his reaction with a smart phone and then publishing it on the Internet); sharing degrading material about a teacher - photos or videos from and outside the school environment and their subsequent commentary; creating teachers' debilitating profiles, threatening and intimidating the teacher, vandalizing the teacher, penetrating the online account of the teacher and then stealing his identity, writing a message in the teacher's name, removing the teacher's work published on the Internet, and making other offensive and insulting statements about the teacher. ${ }^{4}$ It is not just the youngest generation of the already mentioned generations $\mathrm{Z}$ and Alpha.

In general, many people associate the concept of "intelligent" with tremendous knowledge, ingenious thinking, meaningful distinction, positive qualities of being and consciousness, emotional experiences, in terms of machines, computers, or admiring artificial intelligence. However, machine cannot be "intelligent" in the human sense, says Sarah Spiekermann, a business computer scientist from Vienna. According to her, IT professionals would rather not use the notion of "intelligence" at all. The machine can only process certain data based on pre-defined conditions. It is true that machines perform certain human activities, work and performances, but transferring our own ability to perform into our machines is a false exchange. According to the scientist, creating machines or robots like us, people, is to play God. ${ }^{5}$ Technicians should address the issue of developing ways of controlling technology instead of controlling the world by the technology. There are too many examples of this problem. These often culminate in manipulation, pointing to discrimination, persecution or isolation of individuals and entire groups of people.

${ }^{4}$ Cf. Ibid, p. 17.

${ }^{5}$ Cf. Warum Künstliche Intelligenz keineswegs so intelligent ist, „Christ In Der Gegenwart. Katholische Wochenzeitschrift" 2018, no. 48, Freiburg, www.christ-in-der-gegenwart.de, p. 526b (12.12.2018). 


\section{Technicians should address the issue of developing a control of technique instead of controlling the world by the technique.}

\section{THE (REAL OR) ACTUAL NEEDS OF MAN AND SOCIETY}

Joseph Vialatoux ${ }^{6}$ speaks of "metaphysical error", explaining it as follows:

The "development of the sciences, especially since the end of the Enlightenment, has brought about a reduction of modern thought to a single type of rationality, that of scientific reason, which has itself been adapted only to the physical and mathematical sciences, which has become the very model of all knowledge; a kind of double reduction which leads us to believe that all knowledge is not real [actual] knowledge except the one that is developed on the basis of 'scientific facts', as if the act of knowing has been reduced only to the operation of the construction of an object"

The text reminds us to think in a parallel way about the fact that it is possible to admit that most people moving in our society are operating with reduced knowledge and, moreover, doubly reduced knowledge. Can such a person understand their real needs? Hardly. Those needs will be only unrealistic, superficial and artificial. At best, those needs will be harmless, but sometimes they will be superfluous and very often dangerous.

${ }^{6}$ Joseph Vialatoux (1880-1970), a French Catholic philosopher, a leading member of the Catholic social activist Chronique social, with liberal Christian democratic views, a prolific author, journalist, teacher, professor at the Catholic University of Lyon. Along with his contemporary, Jean Lacroix (1900-1986), are two philosophers from Lyon, as well, who, in their works, have deeply engaged in the dialogue between faith and culture and between believing faith and intelligence.

7 „le développement des sciences surtout depuis la fin du siècle des Lumières a provoqué une réduction de la pensée moderne à un seul type de rationalité, celui de la raison scientifique, ramenée elle-même à la seule science physico-mathématique, devenue le modèle même de toute connaissance; double réduction en quelque sorte qui conduit à croire qu'il n'y a de véritable savoir que de ce qui est construit à la manière d'un «fait scientifique», comme si l'acte de connaître se résumait àla seule opération de construction d'un objet“, M.-É. Bély, Face à, p. 151. 
Seeing reality in the right light requires intense, focused human effort and great respect for the truth. This requires hard work of oneself and others, and transmission of experience, knowledge and skills from generation to generation, from person to person.

First, there have been many errors in the pedagogical education of the latest generations because of reduced knowledge and the promotion of such knowledge. Secondly, the transfer of person-to-person knowledge has also been greatly reduced and increasingly replaced by artificial means. Thirdly, there is an increasing lack of original and firm "verification" of knowledge.

Edith Stein pointed to it in her lectures in the 1930s. Because of the rise of National Socialism in Germany, she could not finish the courses she was teaching and so she decided to write her lectures down. We still draw on them with great profit. Her work entitled Der Aufbau der menschlichen Person. Vorlesungen zur philosophischen Anthropologie [Building a Human Person: Lectures on Philosophical Anthropology] is based on the idea that the concept of man is fundamental for all of pedagogical science and education. Hidden in every person is an indefinable "logos". It is like an image, an idea that creates a system or theory, and the person acts according to it, because he knows his own nature. Each theory of human formation is bound to some worldview and metaphysics. It does not have to be consistent. Such an illogical error is also a protection. Only in this way can parents or educators avoid radical erroneous theories. ${ }^{8}$ We can be pleased with these words, especially when we see how new, often reversed ideologies, slip into education and cause considerable confusion. But what does it have to do with digital leadership, the Internet and education?

Today, just as at the time that Edith Stein (20 th century) was writing, there are three human concepts that dominate the fields of education and pedagogy. She calls these main pedagogical theories: $1^{\text {st }}$ the image of man according to German idealism (Humanitätsideal); $2^{\text {nd }}$ picture of depth psychology portrayed by Romantic and Russian writers; $3^{\text {rd }}$ the human being (Dasein) according to the existential philosophy of Heidegger. ${ }^{9}$ Then she compares all three with the Christian image of man. It is a masterpiece with multiple translations.

${ }^{8}$ Cf. E. Stein, Der Aufbau der menschlichen Person. Vorlesungen zur philosophischen Anthropologie, p. 8-9.

${ }^{9}$ Cf. Ibid, p. 9-13. 
These examples relate the consequences of reductionist thinking, which has endured for many decades in distorting images of man's needs. One of the most painful consequences is the loss of sense for reality. Something similar to the parable of the poor Lazarus, who had nothing, and the rich man, who feasted every day: in the end, their roles were entirely reversed, and the rich man ended up in dire need, realizing, too late, that he had completely misread reality.

A former well-known Austrian colleague of mine once said that at a conference on medical ethics, one of the participants announced that he had discovered a way to prolong human life. Everyone there shouted him down; no such discovery was meaningful, they said. My colleague then explained why. Longevity is only meaningful in a cultural context. Medieval people only had a life expectancy of 40-50 years, but they had a vision of eternity. Today, hardly any such vision exists, and so a mere hundred years on this earth is not nearly enough. What is more important: to live a long life or to live meaningfully?

\section{THE INTERNET AND SOCIETY: WHO CONTROLS WHOM?}

The generation that built the Internet has both been served by it and had its life enriched by it. But it seems that the next generation has no other grounding but the Internet, and so to be a part of the digital humanity. We can see it everywhere. Just look at any public place. A generation ago people communicated face to face; now, many of young or less young are immersed in their smartphones. Public behaviour before the smartphone was quite a bit livelier, especially among young people. Whereas one could expect noise and laughter in almost every venue, we now find these same sites cloaked in silence except for the sound of occasional "clicking" or "swiping." Eye contact is a thing of the past. Eyes are now glued to the screens that offer all the distractions that can shield a person from facing reality unless it is of the virtual kind. True, there are exceptions, but without a smartphone, modern life is hardly imaginable.

What does all this mean? It is by now a truism that the younger "internet" generation can teach the older "non-internet" generation easily and authoritatively, but it cannot handle a sense of its own unique existence as easily. The most important thing in life is not technical skill; rather, it is a necessary, but minor, facet to what it means to be a human being. This is also why admiration for technical acuity is receding in the face of a growing concern that these same young 
people have no inkling of their own reality, let alone that of others. It seems that the "computer culture" has enabled the development of what T. S. Eliot has labelled "hollow men," people going around with a vacuum for a brain. How is it possible that a six-year old child can text endless computer messages but can't go to school because he hasn't been toilet-trained? Inventors and other kinds of geniuses might benefit from such developments, but for others, it seems like it is just one more step towards addiction: the computer is the "opium" of youth. Increasing numbers of people are earning their daily bread on the Internet, something that I do as well. What can unlock the gateway to proper, human use of the Internet? I would like to suggest that the image of The Little Prince's Rose might, in some hidden way, contain the answer.

\section{THE “ROSE” GROWN BY THE LITTLE PRINCE}

I was very encouraged by the simple example of a young student who sat opposite me on the high-speed train to Warsaw. He was so concentrated on writing in his notebook that he hardly ever looked up, but I could see that he was contemplating more than he was writing. He was surely as caring for his work as the Little Prince was for his "rose." But I could also "intuit" that his actions were driven and supported by others: one never achieves alone. In the background, I had a vision of all those behind him, starting with his parents, friends, teachers, and of course, by God himself.

\section{CONCLUSIONS}

With the great outcomes of the internet and advanced digital technology, attention must also be paid to some strong negative effects, especially on children and young people (generation $\mathrm{Z}$ and Alpha) - aggressive behaviour of pupils, offensive language on the Internet, insulting authorities, from primary school teachers to top politicians.

IT professionals would rather not use the notion of "intelligence" at all. The machine can only process certain data base on pre-defined conditions. It is true that machines perform certain human activities, work and performances, but transferring into our machines our own ability to perform is a false exchange. Creating machines or robots like us, people, is to play God. 
Technology professionals should address the issue of developing ways to control technology instead of controlling the world with it. Reduction of modern thought to a single way of reasoning (scientific reason and its reduction to the physical and mathematical sciences), a kind of double reduction which leads to believe that knowledge is not real, except the knowledge constructed on the basis of 'scientific fact', reduced to the operation of the construction of an object. The metaphor of "rose" of Little Prince calls us for not to neglect our soul in the era of the Internet.

\section{BIBLIOGRAPHY}

Baer J., The Devil Is in the Details: Why the Answer to Most Questions About Creativity Will Always Be „It Depends", "The Journal Of Creative Behavior” 2017, vol. 51, no 4, p. 275-354.

Bély M.-É., Face à "La personne humaine en péril » Joseph Vialatoux et Jean Lacrois aux Semaines sociales de 1937, in: Gabellieri E. - P. Moreau (ed.), Humanisme et philosophie citoyenne. Jean Lacroix, Joseph Vialatoux. Actes du colloque des 16, 17, 18 janvier 2008, Paris 2010, p. 147-162.

Emmerová I., Učitel' ako obet' kybernetických útokov žiakov. Výskum a prevencia, “Manažment školy v praxi. Odborný mesačník pre školy a školské zariadenia" 10/2018, no 32 p. 17-20.

Gabellieri E. - P. Moreau, Humanisme et philosophie citoyenne. Jean Lacroix, Joseph Vialatoux. Actes du colloque des 16, 17, 18 janvier 2008, Paris 2010.

Stein E., Der Aufbau der menschlichen Person. Vorlesungen zur philosophischen Anthropologie, in: 14 Edith Stein Gesamtausgabe Der Aufbau Der Menschlichen Person, Münster 1932/1933.

Warum Künstliche Intelligenz keineswegs so intelligent ist, in: Christ In Der Gegenwart. Katholische Wochenzeitschrift, no. 48, Freiburg, 2. Dezember 2018, www.christ-inder-gegenwart.de, p. 525-544.

Yoshihara M., Editor's Note, pp. vii-viii, “American Quarterly" 2018, vol.70, no. 3, p. 739.

\section{Biography}

Alžbeta Dufferová was born in Kosice, Slovakia, where she finished the Secondary School of Economics (1970). As a religious sister, she worked for eight years with affected children in Bohemia, and then went to Peru as a missionary. In Lima, she received the title of Teacher of Religion and Social Sciences, Bachelor of Education (1989) and Master of Philosophy (1991). At Charles University in Prague, she received a Ph.D. in philosophy from Systematic Philosophy (1995), in Vienna she became a doctor of Theology, 
Dr. theol. (1998) and in Bratislava an Associate Professor of Theology, Doc. (2003). She spent working one year in Lima at Universidad Marcelino Champagnat, two years at the University of Constantin the Philosopher in Nitra - Slovakia, ten years at the Faculty of Theology at the University of Trnava in Bratislava, ten years at the Faculty of Arts at the University of Trnava,Trnava, and since September 1, 2018 she has worked at the Higher School of Religion Science of Győr, Hungary. 